\title{
The effect of different high-heel types on muscle activation of the paraspinal muscles during standing
}

\author{
Dongwook Han
}

From 4th Congress of the International Foot and Ankle Biomechanics (i-FAB) Community

Busan, Korea. 8-11 April 2014

\section{Purpose}

This study researched the effects of high heels which are same in height that is $8 \mathrm{~cm}$, but different in types that are Wedge heel, Setback heel and French heel on muscle activation of the paraspinal muscles surrounding cervical, thoracic and lumbar spine.

\section{Subject}

The 28 subjects of this study were females in their 20 s, with a foot size of $225 \sim 230 \mathrm{~mm}$ and a normal gait pattern, who had no foot deformities or muscle problems. They voluntarily signed a consent form after hearing the experiment methods.

\section{Methods}

To measure the muscle activations of the C6, T7 and L5 paraspinal muscles and lumbar multifidus during standing, EMG (Keypoint, Medrtonic, USA) was used. After breathing was calmed down, muscle activation during standing on the ground with bare foot was measured. Subsequently, muscle activation during standing wearing shoes with $8 \mathrm{~cm}$ Wedge heel, Setback heel and French heel were measured. The average values of three measurements were used for analysis.

\section{Result}

In the result of examining the effects of heel types, muscle activation of cervical paraspinal muscle induced by Wedge heel, Setback heel and French heel was significantly higher than being on bare foot. However, there was no difference significantly between the heel types. Muscle activation of lumbar paraspinal muscle induced by Wedge heel, Setback heel and French heel was significantly higher than being on bare foot. However, there was no difference significantly between the heel types.

\section{Conclusions}

The height of the heels is a more important variable than the width of the heels about the change of muscle activation of cervical and lumbar paraspinal muscle. So, wearing high-heeled shoes is not recommended to those who have pain and dysfunction in cervical and lumbar region.

Published: 8 April 2014

doi:10.1186/1757-1146-7-S1-A116

Cite this article as: Han: The effect of different high-heel types on

muscle activation of the paraspinal muscles during standing. Journal of Foot and Ankle Research 2014 7(Suppl 1):A116.

Submit your next manuscript to BioMed Central and take full advantage of:

- Convenient online submission

- Thorough peer review

- No space constraints or color figure charges

- Immediate publication on acceptance

- Inclusion in PubMed, CAS, Scopus and Google Scholar

- Research which is freely available for redistribution 